\title{
Gill rakers in six teleost species: influence of feeding habit and body size
}

\author{
Rastros branquiais em seis espécies de teleósteos: influência do \\ hábito alimentar e tamanho corporal
}

\begin{abstract}
Ana Paula Gottlieb Almeida ${ }^{\mathrm{I}}$ Everton Rodolfo Behr ${ }^{\mathrm{II}}$ Bernardo Baldisserotto ${ }^{\mathrm{III}}$
\end{abstract}
\section{ABSTRACT}

This study analyzed the structure of the gill rakers of Parapimelodus valenciennis and Parapimelodus nigribarbis (planktivorous), Serrasalmus maculatus and Hoplias malabaricus (piscivorous), Iheringichthys labrosus (benthophagous) and Hypostomus commersonii (detritivorous) and related it with the body size and feeding habits of these species. The species of Parapimelodus and H. commersonii showed long, filiform and closely spaced gill rakers, similar to those of species that use the gill rakers as a filter to assist in the retention of small particles. The widely spaced gill rakers of I. labrosus probably allow the retention of insect larvae, but not particles of inorganic matter. In $\boldsymbol{H}$. malabaricus and $\boldsymbol{S}$. maculatus the gill rakers are most likely related to prey capture and swallowing, as observed in other piscivorous species. In general, gill raker length and the distance between gill rakers have a positive relationship with fish length. The gill rakers show adaptations related to the diet of the fish, but morphological variation may occur even between species whose feeding habits are the same.

Key words: filtering, gill arches, feeding behavior.

\section{RESUMO}

Este estudo analisou a estrutura dos rastros branquiais de Parapimelodus valenciennis e Parapimelodus nigribarbis (planctívoro), Serrasalmus maculatus e Hoplias malabaricus (piscívoros), Iheringichthys labrosus (bentófago) e Hypostomus commersonii (detritívoro) e a relacionou com o tamanho corporal e hábito alimentar dessas espécies. As espécies de Parapimelodus e $\boldsymbol{H}$. commersonii apresentaram rastros branquiais longos, filiformes e próximos entre si, similar àquelas que usam os rastros branquiais como um filtro para ajudar na retenção de partículas pequenas. Os rastros branquiais espaçados de I. labrosus provavelmente permitem a retenção de larvas de insetos, mas não de partículas de matéria inorgânica. Em $\boldsymbol{H}$. malabaricus e S. maculatus, os rastros branquiais são mais relacionados à captura da presa e deglutição, como observado em outras espécies piscívoras. Em geral, o comprimento do rastro branquial e a distância entre os rastros branquiais tem uma relação positiva com o comprimento do peixe. Os rastros branquiais apresentam adaptações relacionadas com a dieta do peixe, mas variações morfológicas podem ocorrer mesmo entre espécies cujos hábitos alimentares são os mesmos.

Palavras-chave: filtração, arcos branquiais, comportamento alimentar.

\section{INTRODUCTION}

The gill rakers are cartilaginous or bony structures that project to the inside of the pharyngeal cavity and whose structure changes according to the feeding habit of the fish. In planktivorous and detritivorous fishes, the gill rakers are numerous, filiform and near each other, functioning as an efficient filter (DELARIVA \& AGOSTINHO, 2001; RODRIGUES et al., 2006). These structures become increasingly complex as the fish grows, with a significant increase of gill rakers and development of spines (ROSS et al. 2006). In fish with carnivorous feeding habits, the gill rakers are long, hard and pointed, constituting an adaptation to protect the gills, prevent the escape of the prey and assist in swallowing (RODRIGUES \& MENIN, 2006a, b; MACIEL et al. 2009). Gill rakers covered with spines

IPrograma de Pós-graduação em Biodiversidade Animal, Universidade Federal de Santa Maria (UFSM), Santa Maria, RS, Brasil.

IDepartamento de Zootecnia, UFSM, Santa Maria, RS, Brasil.

IIIPrograma de Pós-graduação em Zootecnia, Departamento de Fisiologia e Farmacologia, UFSM, 97105-900, Santa Maria, RS, Brasil. E-mail: bbaldisserotto@hotmail.com. Autor para correspondência. 
assist in scraping food and prevent regurgitation (RODRIGUES et al., 2006).

Previous studies analyzed gill rakers and their adaptations related to feeding in species with the same feeding habit (LANGELAND \& NØST, 1995; EIRAS-STOFELLA \& CHARVET-ALMEIDA, 1997) or related gill rakers to species identification (LUCENA et al., 1992). Most previous studies addressing digestive tract structure did not describe the gill rakers in detail. Therefore, this study analyzed the structure of the gill rakers of six neotropical species and related it with the body size and feeding habits of these species.

\section{MATERIALS AND METHODS}

Specimens of piscivorous Serrasalmus maculatus (Kner, 1858; Serrasalmidae) (BEHR \& SIGNOR, 2008) $(\mathrm{n}=14 ;$ 9.9-15.6cm $)$, Hoplias malabaricus (Bloch, 1749; Erythrinidae) (MORAES \& BARBOLA, 1995) $(n=12 ; 11.6-$ $26.5 \mathrm{~cm}$ ), detritivorous Hypostomus commersonii (Valenciennes, 1836; Loricariidae) ( $\mathrm{n}=12$; 18.1$27.5 \mathrm{~cm}$ ), planktivorous Parapimelodus valenciennis (Lütken, 1874; Pimelodidae) (ROSSO, 2006) (n=13; 9.9-15.6cm) and benthophagous Iheringichthys Iabrosus (Lütken 1874; Pimelodidae) (ABES et al., 2001) ( $\mathrm{n}=13$; 9.2-17.5cm) were collected in the Ibicuí River, and planktivorous Parapimelodus nigribarbis (Boulenger, 1889; Pimelodidae) (LUCENA et al., 1992) ( $\mathrm{n}=15 ; 11-18 \mathrm{~cm})$ was collected in the Vacacaí River. Both rivers are in Rio Grande do Sul state, southern Brazil. The collected fishes were fixed with $10 \%$ formalin and subsequently preserved in $70 \%$ alcohol. In the laboratory, the standard length of the fishes was measured, the gills removed and the gill arches separated. The length of the gill rakers and their spines, as well as the distances between gill rakers and between spines (Figure 1), were analyzed with an optical microscope (100-400x magnification) and measurements made with an ocular micrometer.

To verify the homogeneity of the variances, the data on the measured parameters were evaluated with a Levene test. The data that showed homogeneous variances were compared with a one-way ANOVA followed by a Tukey test. Some data were transformed logarithmically to obtain homogeneous variances. The distance between the gill rakers of the first gill arch, the distance between the spines of the fourth gill arch, the number of gill rakers per gill arch and the number of spines per gill raker did not show homogeneous variances and were analyzed with a Kruskal-Wallis ANOVA followed by a multiple comparisons test of means by ranks. Statistica (version 7.0, StatSoft Inc., Tulsa, OK, USA) was used for all statistical analysis. The relationships between the different measured parameters and fish length were calculated with Sigma Plot 11.0. The minimum significance level was set at $\mathrm{P}<0.05$.

\section{RESULTS}

The number of gill rakers in the first gill arch was significantly lower in S. maculatus, H. malabaricus and $\boldsymbol{I}$. labrosus than in the other studied species (except $\boldsymbol{P}$. valenciennis compared to $\boldsymbol{S}$. maculatus) (Table 1). The number of spines in the first gill raker was significantly lower in $\boldsymbol{S}$. maculatus and $\mathbf{I}$. labrosus than in the other studied species (except $\boldsymbol{H}$. malabaricus) (Table 2).

The length of the gill rakers decreased significantly from the first to the fourth gill arch in $\boldsymbol{P}$. nigribarbis and $\boldsymbol{P}$. valenciennis. No significant differences were found in the distance between the rakers and in the length of the spines in these species. In $\boldsymbol{P}$. valenciennis, the distance between the spines was higher in the fourth gill arch than in the others. In $\boldsymbol{P}$. nigribarbis, the distance between the spines of the first gill arch was higher than the corresponding distance in the fourth gill arch.

The length of the gill rakers was highest in the first gill arch and did not differ among the other arches in S. maculatus. The first gill arch showed higher distances between the rakers than the third arch. No significant differences were found in the spine length or the distance between the spines in the gill arches of this species. Iheringichthys Iabrosus and $\boldsymbol{H}$. malabaricus had gill rakers only in the first gill arch. Hypostomus commersonii did not show any significant differences between the gill arches in the values of the parameters measured.

The length of the gill rakers in the first gill arch was highest in both species of Parapimelodus, followed, in decreasing order, by $\boldsymbol{H}$. commersonii, H. malabaricus, I. labrosus and S. maculatus. In the second, third and fourth gill arches, $\boldsymbol{H}$. commersonii showed the highest gill raker length, $\boldsymbol{S}$. maculatus the smallest.

In the first gill arch, both species of Parapimelodus and H. commersonii did not show any significant differences in the measured parameters. These three species showed the smallest distance between the gill rakers, followed by $\boldsymbol{S}$. maculatus, I. labrosus and $\boldsymbol{H}$. malabaricus, in ascending order. In the second, third and fourth arches, both species of Parapimelodus and $\boldsymbol{H}$. commersonii showed the lowest distance between the gill rakers, whereas $\boldsymbol{S}$. maculatus showed the highest. 


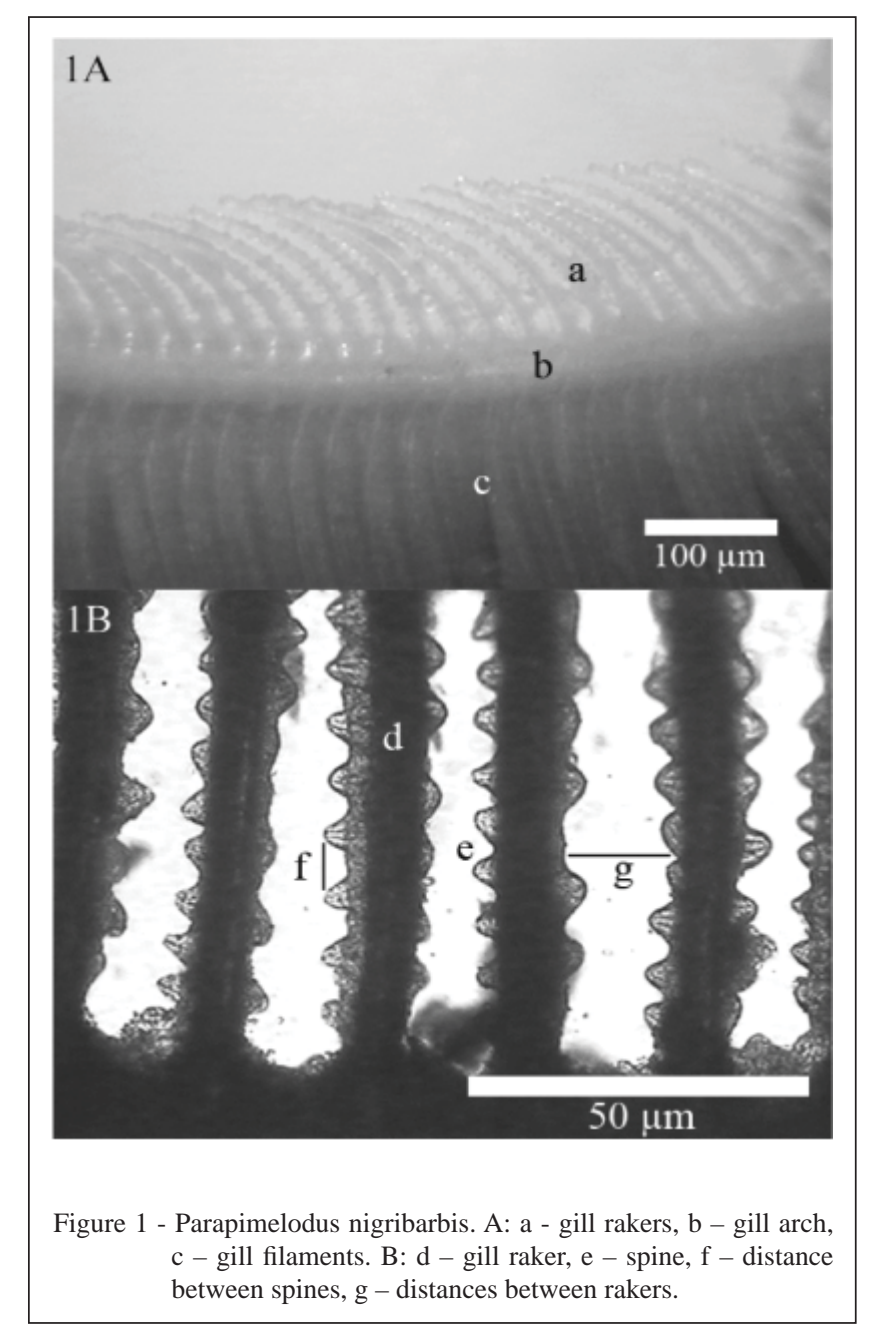

The highest spine length in the first gill arch was found in $\boldsymbol{H}$. malabaricus, followed, in decreasing order, by I. labrosus, P. nigribarbis, S. maculatus and $\boldsymbol{P}$. valenciennis. In the second and third gill arch, $\boldsymbol{P}$. nigribarbis showed the highest spine length. The highest spine length in the fourth gill arch was found in S. maculatus and $\boldsymbol{P}$. nigribarbis. Parapimelodus valenciennis showed the lowest spine length in the fourth arch. Hypostomus commersonii did not show any significant differences from the other species.

In the first gill arch, $\boldsymbol{H}$. commersonii showed the lowest distance between spines. No significant difference in this parameter was found among the other species. In the second gill arch, the distance between spines was higher in both species of Parapimelodus. In the third gill arch, this distance was the highest in $\boldsymbol{P}$. valenciennis, followed, in decreasing order, by $\boldsymbol{S}$. maculatus, $\boldsymbol{P}$. nigribarbis and $\boldsymbol{H}$. commersonii. Both species of Parapimelodus showed a higher distance between spines in the fourth arch than $\boldsymbol{H}$. commersonii.

The length of the gill rakers increased in proportion to the length of the fish in $\boldsymbol{P}$. nigribarbis and $\boldsymbol{P}$. valenciennis (except in the fourth gill arch in this species), in the second gill arch of $\boldsymbol{S}$. maculatus, in the two first gill arches of $\boldsymbol{H}$. commersonii and in the first gill arch of $\boldsymbol{I}$. labrosus and $\boldsymbol{H}$. malabaricus. The distance between gill rakers also increased with fish length in the first and second gill arches of $\boldsymbol{P}$. valenciennis and in the first gill arch of I. labrosus and $\boldsymbol{H}$. malabaricus (Table 1). The spine length and the distance between spines had a weak relationship with fish length in all gill arches except the first gill arch of $\boldsymbol{I}$. labrosus (Table 2).

\section{DISCUSSION}

The gill rakers of $\boldsymbol{H}$. malabaricus and $\boldsymbol{S}$. maculatus show different characteristics, but both 
Table 1 - Relationships between fish length and gill raker length and between fish length and distance between gill rakers. n: mean number of gill rakers by gill arch. Equations: $\mathrm{y}=\mathrm{a}+\mathrm{bx}$, where $\mathrm{y}=$ gill raker length or distance between gill rakers (in $\mathrm{mm}), \mathrm{x}=$ fish length $(\mathrm{cm})$, "a" and "b" = coefficients of the equations.

\begin{tabular}{|c|c|c|c|c|c|c|c|}
\hline \multirow{2}{*}{ Species } & \multirow[b]{2}{*}{$\mathrm{n}$} & \multicolumn{3}{|c|}{--------------------Length---------------------- } & \multicolumn{3}{|c|}{--------------------Distance-------. } \\
\hline & & a & $\mathrm{b}$ & $\mathrm{r}^{2}$ & a & $\mathrm{b}$ & $\mathrm{r}^{2}$ \\
\hline \multicolumn{8}{|c|}{ P. valenciennis } \\
\hline First arch & $55.6^{\mathrm{AB}}$ & 15.46 & 44.47 & 0.707 & 1.19 & 0.27 & 0.802 \\
\hline Second arch & 63.5 & 7.4 & -1.59 & 0.853 & 1.31 & -1.47 & 0.717 \\
\hline Third arch & 57.5 & 5.06 & -3.28 & 0.908 & 1.28 & 0.25 & 0.619 \\
\hline Fourth arch & 48.5 & 2.21 & 11.96 & 0.289 & 0.7 & 6.32 & 0.280 \\
\hline \multicolumn{8}{|l|}{ P. nigribarbis } \\
\hline First arch & $59^{\mathrm{A}}$ & 36.48 & -240.45 & 0.933 & 0.74 & 3.98 & 0.398 \\
\hline Second arch & 54.4 & 13.95 & -89.90 & 0.936 & 1.04 & 0.54 & 0.528 \\
\hline Third arch & 48 & 9.11 & -55.24 & 0.880 & 0.94 & 2.16 & 0.429 \\
\hline Fourth arch & 44.5 & 5.33 & -27.41 & 0.766 & 0.73 & 3.82 & 0.245 \\
\hline \multicolumn{8}{|l|}{ S. maculatus } \\
\hline First arch & $14^{\mathrm{BC}}$ & 2.65 & 3.57 & 0.526 & 2.87 & 25.53 & 0.440 \\
\hline Second arch & 15.5 & 2.62 & -6.41 & 0.704 & 2.89 & 16.22 & 0.481 \\
\hline Third arch & 14.5 & 1.58 & 5.82 & 0.450 & 2.11 & 24.58 & 0.439 \\
\hline Fourth arch & 9.7 & 1.37 & 9.33 & 0.427 & 2.64 & 18.14 & 0.331 \\
\hline \multicolumn{8}{|c|}{ H. commersonii } \\
\hline First arch & $86.2^{\mathrm{A}}$ & 7.24 & -21.54 & 0.790 & 0.18 & 9.3 & 0.308 \\
\hline Second arch & 98.9 & 6.32 & -1.26 & 0.749 & 0.09 & 11.42 & 0.039 \\
\hline Third arch & 112 & 5.71 & 12.83 & 0.522 & 0.1 & 11.35 & 0.189 \\
\hline Fourth arch & 117.8 & 3.16 & 62.75 & 0.484 & 0.32 & 6.34 & 0.446 \\
\hline \multicolumn{8}{|l|}{ I. labrosus } \\
\hline First arch & $12.8^{\mathrm{C}}$ & 5.42 & 0.3 & 0.863 & 5.41 & -11.18 & 0.821 \\
\hline \multicolumn{8}{|c|}{ H. malabaricus } \\
\hline First arch & $5.1^{\mathrm{C}}$ & 5.32 & -13.02 & 0.749 & 8.72 & -19 & 0.739 \\
\hline
\end{tabular}

Different capital letters indicate significant differences between species $(\mathrm{P}<0.05)$.

species have the same piscivorous feeding habit. The gill rakers of $\boldsymbol{S}$. maculatus are short and triangular, less widely spaced and more numerous than in $\boldsymbol{H}$. malabaricus. Both species show spines covering the rakers. Hoplias lacerdae (Miranda Ribeiro, 1908; Erythrinidae), a piscivorous species, shows the same pattern found in $\boldsymbol{H}$. malabaricus (MACIEL et al., 2009). The same characteristics found in S. maculatus were described for Serrasalmus marginatus (Valenciennes, 1837; Serrasalmidae) (PERETTI \& ANDRIAN, 2008), Pseudoplatystoma corruscans (Spix \& Agassiz, 1829; Pimelodidae) and Salminus brasiliensis (Cuvier, 1816; Characidae) (RODRIGUES \& MENIN, 2006a, b), and in these species gill rakers participate in the capture and seizure of prey in these species. Species that feed on fishes, the remains of fishes, insects and the remains of plants do not need long and abundant gill rakers (MORAES \& BARBOLA, 1995; VILLARES JUNIOR et al., 2008), as observed in $\boldsymbol{H}$. malabaricus and $\boldsymbol{S}$. maculatus in the present study.
The gill rakers of $\mathbf{I}$. Iabrosus are short, laminar, widely spaced and covered with spines. The diet of this species consists primarily of aquatic insects (Chironomidae) and mollusks (Bivalvia) (ABES et al., 2001). The widely spaced gill rakers of this species allow the retention of larvae, whereas particles of inorganic matter, such as sand, are rejected (FUGI et al., 2001). The benthophagous species Umbrina coroides (Cuvier, 1830; Sciaenidae) (ZAHORCSAK et al., 2000) and Loricaria lentiginosa (Isbrücker, 1979; Loricariidae) (SALVADOR-JR et al., 2009) use the same mechanism to select food and eliminate grains of sand through the rakers.

In $\boldsymbol{H}$. commersonii, the gill rakers are long, closely spaced, covered with spines and located parallel to the gill filaments, covering only half of the filaments. This characteristic indicates a strategy for the protection of these structures (EIRAS-STOFELLA \& CHARVET-ALMEIDA, 1997). The same pattern was found by DELARIVA \& AGOSTINHO (2001) in other species of detritivorous fishes. However, 
Table 2 - Relationships between fish length and spine length and between fish length and distance between spines. n: mean number of spines by gill arch. Equations: $y=a+b x$, where $y=$ spine length or distance between spines (in $\mathrm{mm}), \mathrm{x}=$ fish length $(\mathrm{cm})$, “a” and "b” = coefficients of the equations.

\begin{tabular}{|c|c|c|c|c|c|c|c|}
\hline \multirow{2}{*}{ Species } & \multirow[b]{2}{*}{$\mathrm{n}$} & \multicolumn{3}{|c|}{------------------------Length----------------------- } & \multicolumn{3}{|c|}{---------------------Distance------ } \\
\hline & & a & $\mathrm{b}$ & $\mathrm{r}^{2}$ & $\mathrm{a}$ & $\mathrm{b}$ & $\mathrm{r}^{2}$ \\
\hline \multicolumn{8}{|c|}{ P. valenciennis } \\
\hline First arch & 84.3 & 0.02 & 3.18 & 0.001 & 0.73 & -1.26 & 0.039 \\
\hline Second arch & 70.1 & -0.04 & 3.87 & 0.009 & 0.65 & -0.81 & 0.672 \\
\hline Third arch & 47.6 & -0.08 & 4.24 & 0.020 & 0.5 & 0.81 & 0.341 \\
\hline Fourth arch & 28.9 & 0.18 & 0.21 & 0.331 & 0.03 & 4.89 & 0.011 \\
\hline \multicolumn{8}{|l|}{ P. nigribarbis } \\
\hline First arch & 103.1 & 0.54 & -1.52 & 0.494 & -0.19 & 9.37 & 0.039 \\
\hline Second arch & 77.3 & 0.5 & -1.47 & 0.578 & 0.16 & 3.97 & 0.093 \\
\hline Third arch & 53.9 & 0.38 & 0.12 & 0.405 & -0.21 & 3.11 & 0.135 \\
\hline Fourth arch & 36.7 & 0.29 & 0.34 & 0.309 & 0.31 & 1.13 & 0.282 \\
\hline \multicolumn{8}{|c|}{ H. commersonii } \\
\hline First arch & 72.1 & -0.04 & 4.59 & 0.060 & -0.04 & 4.6 & 0.059 \\
\hline Second arch & 78.4 & -0.08 & 5.19 & 0.293 & -0.03 & 4.51 & 0.026 \\
\hline Third arch & 101.4 & -0.03 & 4.35 & 0.036 & -0.01 & 4.07 & 0.004 \\
\hline Fourth arch & 103.2 & -0.01 & 3.71 & 0.013 & -0.11 & 5.97 & 0.183 \\
\hline \multicolumn{8}{|l|}{ S. maculatus } \\
\hline First arch & 21.4 & 0.11 & 2.99 & 0.034 & 0.69 & -3.62 & 0.314 \\
\hline Second arch & 19.1 & -5.74 & 3.87 & 0.001 & 0.48 & -2.11 & 0.506 \\
\hline Third arch & 18.1 & 0.03 & 3.21 & 0.015 & 0.12 & 3.35 & 0.042 \\
\hline Fourth arch & 15.1 & 0.15 & 1.56 & 0.218 & 0.67 & -4.08 & 0.264 \\
\hline \multicolumn{8}{|l|}{ I. labrosus } \\
\hline First arch & 5.4 & 1.23 & -10.26 & 0.569 & -4.37 & -38.13 & 0.742 \\
\hline \multicolumn{8}{|c|}{ H. malabaricus } \\
\hline First arch & 38.7 & 0.5 & 2.5 & 0.433 & -0.08 & 10.44 & 0.045 \\
\hline
\end{tabular}

Steindachnerina brevipinna (Eigenmann \& Eigenmann, 1889; Curimatidae) and Satanoperca pappaterra (Heckel, 1840; Cichlidae) show gill rakers differing from those of $\boldsymbol{H}$. commersonii, although these species and $\boldsymbol{H}$. commersonii have the same feeding habit. The rakers of these species are short, filiform, closely spaced and located opposite the gill filaments (HAHN \& CUNHA, 2005; LIMA et al., 2009).

The species of Parapimelodus analyzed in the present study have long, filiform and closely spaced gill rakers. This type of gill rakers is characteristic of planktivorous species such as Anchoa januaria (Steindachner, 1879; Engraulidae) and Centegraulis edentulus (Cuvier, 1839; Engraulidae) (SERGIPENSE et al., 1999). It is probable that both species of Parapimelodus use filtering to feed and that the gill rakers act as a filter for retaining particles.

The first gill arch presents longer gill rakers in most species analyzed in the present study. The same was observed in Chirostoma estor estor
(Jordan, 1880; Atherinopsidae) (ROSS et al., 2006) and Rita rita (Hamilton, 1822; Bagridae) (KUMARI et al., 2005). The relationship between fish length and gill raker length detected in most of the species examined in the present study is also found in $\boldsymbol{A}$. januaria and $C$. edentulus (SERGIPENSE et al., 1999). During growth in C. estor estor, the gill rakers become more complex; moreover, the distance between the gill rakers and the distance between the spines increase. A possible explanation of these changes is that juveniles ingest smaller particles than do adults, but difference in prey ingestion with age may also reflect changes in fish swimming abilities (ROSS et al., 2006). The present study found that the distance between gill rakers increased with fish length only in $\boldsymbol{P}$. valenciennis, I. Iabrosus and $\boldsymbol{H}$. malabaricus. This distance increases with the degree of bucal cavity expansion, and several species feed on prey of the same size regardless of differences in the distance between gill rakers (LANGELAND \& NØST, 1995). In addition, instead of dead-end filtration, several planktivore species use crossflow 
filtration, in which the major flow is parallel to the filter surface and particles aggregate together on the surface of the filter to form clumps that are much larger than the apparent pore size (ROSS et al., 2006; SMITH \& SANDERSON, 2007).

The results of the present study demonstrated that the characteristics of the gill rakers (rakers and spines length, distance between rakers and spines) may vary between gill arches of the same species, and also with the fish size. Therefore, comparisons between species must be between fish of the same size and with the same gill arch. The characteristics of the gill rakers of the studied species allow the conclusion that these structures show adaptations related to the diet of the fish but that morphological variation may also occur, even between species that show the same feeding habit. In general, gill raker length and the distance between gill rakers showed a positive relationship with fish length. However, there was no relationship between fish length and spine length or the distance between spines.

\section{REFERENCES}

ABES, S.S. et al. Diet of Iheringichthys labrosus (Pimelodidae Siluriformes) in the Itaipu Reservoir, Paraná River, BrazilParaguay. Brazilian Archives of Biology and Technology, v.44, n.1, p.101-105, 2001. Available from: <http://www.scielo.br/pdf/ babt/v44n1/a14v44n1.pdf>. Accessed: Dez. 20, 2012.

BEHR, E.R.; SIGNOR, C.A. Distribuição e alimentação de duas espécies simpátricas de piranhas Serrasalmus maculatus e Pygocentrus nattereri (Characidae, Serrasalminae) do rio Ibicuí, Rio Grande do Sul, Brasil. Iheringia, Série Zoologia, v.98, n.4 p.501-507, 2008. Available from: <http://www.scielo.br/pdf/isz/ v98n4/v98n04a14.pdf>. Accessed: 20 dez. 2012.

DELARIVA, R.L.; AGOSTINHO, A.A. Relationship between morphology and diets of six neotropical loricariids. Journal of Fish Biology, v.58, p.832-847, 2001. Available from: <http:// onlinelibrary.wiley.com/doi/10.1111/j.1095-8649.2001.tb00534.x/ pdf>. Accessed: 20 dez. 2012. doi: 10.1006/jfbi.2000.1499.

EIRAS-STOFELLA, D.R.; CHARVET-ALMEIDA, P. Gills of the freshwater fish Hypostomus commersonii Val., 1840 (Loricariidae) analyzed through electron microscopy techniques. Brazilian Archives of Biology and Technology, v.40, p.785-792, 1997.

FUGI, R. et al. Trophic morphology of five benthic-feeding fish species of a tropical floodplain. Revista Brasileira de Biologia, v.61, n.1, p.27-33, 2001. Available from: <http://www.scielo.br/ pdf/rbbio/v61n1/a05v61n1.pdf>. Accessed: 20 dez. 2012. doi: 10.1590/S0034-71082001000100005.

HAHN, N.S.; CUNHA, F. Feeding and trophic ecomorphology of Satanoperca pappaterra (Pisces, Cichlidae) in the Manso Reservoir, Mato Grosso State, Brazil. Brazilian Archives of Biology and Technology, v.48, n.6, p.1007-1012, 2005. Available from: <http:// www.scielo.br/pdf/babt/v48n6/27446.pdf>. Accessed: 20 dez. 2012. doi: 10.1590/S1516-89132005000800017.
KUMARI, U. et al. Morphology of the pharyngeal cavity, especially the surface ultrastructure of gill arches and gill rakers in relation to the feeding ecology of the catfish Rita rita (Siluriformes, Bagridae). Journal of Morphology, v.265, p.197208, 2005. Available from: <http://onlinelibrary.wiley.com/ doi/10.1002/jmor.10350/pdf.> Accessed: 31 maio, 2013. doi: 10.1002/jmor.10350.

LANGELAND, A.; NØST, T. Gill raker structure and selective predation on zooplankton by particulate feeding fish. Journal of Fish Biology, v.47, p.719-732, 1995. Available from: <http://onlinelibrary. wiley.com/doi/10.1111/j.1095-8649.1995.tb01937.x/pdf>. Accessed: 20 dez. 2012. doi: 10.1111/j.1095-8649.1995.tb01937.x.

LIMA, F.B. et al. Morfologia das brânquias de Steindachnerina brevipinna (Eigenmann \& Eigenmann, 1889) (Characiformes, Curimatidae). Revista Biotemas v.22, n.1, p.87-92, 2009. Available from: <http://www.biotemas.ufsc.br/volumes/pdf/volume221/pdf87a92. pdf $>$. Accessed: 20 dez. 2012.

LUCENA, C.A.S. et al. Resurrection of the Neotropical Pimelodid Catfish Parapimelodus nigribarbis (Boulenger), with a Phylogenetic Diagnosis of the Genus Parapimelodus (Teleostei: Siluriformes). Copeia, v.1, p.138-146, 1992. Available from: <http://www.jstor.org/discover/10.2307/1446545 ?uid $=3737664$ \&uid $=2129$ \&uid $=2134$ \&uid $=2$ \&uid $=70$ \&uid $=4 \&$ s id=21101579018131>. Accessed: 20 dez. 2012.

MACIEL, C.M.R.R. et al. Anatomia funcional da cavidade bucofaringiana de trairão, Hoplias lacerdae Miranda Ribeiro, 1908 (Characiformes, Erythrinidae). Revista Biotemas, v.22, n.3, p.95-102, 2009. Available from: <http://www.biotemas.ufsc. br/volumes/pdf/volume223/95a102.pdf>. Accessed: 20 dez. 2012.

MORAES, M.F.P.G.; BARBOLA, I.F. Hábito alimentar e morfologia do tubo digestivo de Hoplias malabaricus (Osteichthyes, Erythrinidae) da Lagoa Dourada, Ponta Grossa, Paraná, Brasil. Acta Biológica Paranaense, v.24, p.1-23, 1995. Available from: <http://ojs.c3sl.ufpr.br/ojs-2.2.4/index.php/acta/ article/viewArticle/700>. Accessed: 20 dez. 2012.

PERETTI, D.; ANDRIAN, I.F. Feeding and morphological analysis of the digestive tract of four species of fish (Astyanax altiparanae, Parauchenipterus galeatus, Serrasalmus marginatus and Hoplias aff. malabaricus) from the upper Paraná River floodplain, Brazil. Brazilian Journal of Biology, v.68, n.3, p.671-679, 2008. Available from: <http:// www.scielo.br/pdf/bjb/v68n3/a27v68n3.pdf>. Accessed: 20 dez. 2012. doi: 10.1590/S1519-69842008000300027.

RODRIGUES, S.S. et al. Adaptações anatômicas da cavidade bucofaringiana de Leporinus macrocephalus Garavello \& Britski, 1988 (Pisces, Characiformes, Anostomidae) em relação ao hábito alimentar. Revista Biotemas, v.19, n.1, p.51-58, 2006. Available from: <http://www.biotemas.ufsc.br/volumes/ pdf/volume191/ p51a58.pdf>. Accessed: 20 dez. 2012.

RODRIGUES, S.S.; MENIN, E. Anatomia da cavidade bucofaringeana de Salminus brasiliensis (Cuvier, 1817) (Pisces, Characidae, Salmininae). Revista Biotemas, v.19, n.1, p.41-50, 2006a. Available from: <http://www.biotemas.ufsc.br/volumes / pdf/volume191/p41a50.pdf>. Accessed: 20 dez. 2012.

RODRIGUES, S.S.; MENIN, E. Adaptações anatômicas da cavidade bucofaringiana de Pseudoplatystoma corruscans (Spix e Agassiz, 1829) (Siluriformes, Pimelodidae) em relação ao seu hábito alimentar. Revista Ceres, v.53, n.305, p.135-146, 2006b. Available 
from: <http://www.ceres.ufv.br/CERES/revistas/V53N305P01906. pdf $>$. Accessed: 20 dez. 2012.

ROSS, L.G. et al. Determination of feeding mode in fishes: the importance of using structural and functional feeding studies in conjunction with gut analysis in a selective zooplanktivore Chirostoma estor estor Jordan 1880. Journal of Fish Biology, v.68, p.1782-1794, 2006. Available from: <http://onlinelibrary. wiley.com/doi/10.1111/j.1095-8649.2006.01061.x/pdf>. Accessed: 20 dez. 2012. doi: 10.1111/j.1095-8649.2006.01061.x.

ROSSO, J.J. Peces pampeanos: guía y ecología. Buenos Aires: L.O.L.A., 2006. 221p.

SALVADOR-JR. L.F. et al. Morphology of the digestive tract and feeding habits of Loricaria lentiginosa Isbrücker, 1979 in a Brazilian reservoir. Acta Zoologica (Stockholm), v.90, p.101109, 2009. Available from: <http://onlinelibrary.wiley.com/ doi/10.1111/j.1463-6395.2008.00336.x/pdf>. Accessed: $20 \mathrm{dez}$. 2012. doi: 10.1111/j.1463-6395.2008.00336.x.

SMITH, J.C.; SANDERSON, S.L. Mucus function and crossflow filtration in a fish with gill rakers removed versus intact. Journal of
Experimental Biology, v.210, p.2706-2713, 2007. Available from: <http://jeb.biologists.org/content/210/15/2706.full.pdf+html>. Accessed: 20 dez. 2012. doi: 10.1242/jeb.000703.

SERGIPENSE, S. et al. Morfologia e hábitos alimentares de duas espécies de Engraulidae (Teleostei, Clupeiformes) na Baía de Sepetiba, Rio de Janeiro. Revista Brasileira de Oceanografia, v.47, n.2, p.173-188, 1999. Available from: <http://www.scielo.br/ pdf/bjoce/v47n2/06.pdf>. Accessed: 20 dez. 2012.

VILLARES JUNIOR, G.A. etal. Alimentação de Serrasalmus maculatus (Kner, 1858) (Characiformes; Serrasalmidae) no trecho inferior bacia do rio Sorocaba, São Paulo, Brasil. Acta Scientiarum Biological Sciences, v.30, n.3, p.267-273, 2008. Available from: <http://periodicos.uem.br/ ojs/index.php/ActaSciBiolSci/article/view/5011/5011>. Accessed: 20 dez. 2012. doi: 10.4025/actascibiolsci.v30i3.5011.

ZAHORCSAK, P. et al. Feeding biology of a guild of benthivorous fishes in a sandy shore on south-eastern Brazilian coast. Revista Brasileira de Biologia, v.60, n.3, p.511-518, 2000. Available from: <http:/www.scielo.br/scielo.php?pid=S003471082000000300016\&script=sci_arttext $>$. Accessed: 20 dez. 2012. doi: /10.1590/S0034-71082000000300016. 